\title{
Pharmacoepidemiology - A Lot beyond Pencil and Paper Research
}

\author{
Suman Garlapati* \\ Drug Safety \& Pharmacovigilance Officer, InvaGen Pharmaceuticals, Inc. Hauppauge, New York 11788, USA
}

Pharmacoepidemiology came into its own sometime in the late seventies, as a specialty which linked clinical pharmacology to epidemiology [1], at a time when it became increasingly evident, that factors affecting drug use by the community played a critical role in the success or failure of drug therapy. Hailed as a "research tool of global importance," 1 the World Health Organization too promoted research into this key area by conducting workshops, publishing manuals, training investigators and encouraging research by funding projects $[2,3]$. In Germany this sub-specialty has found a niche among pharmacologists who are happy to embrace it as "pencil and paper" research, more for reasons of convenience rather than that of genuine interest. Dwindling financial support for research from the administration of many medical colleges, along with the difficulty faced in procuring and maintaining laboratory animals or recruiting patients/healthy volunteers [4], as well as the problems faced in conducting experiments - ranging from poor quality of reagents to maintenance and upkeep of equipment have literally pushed many researchers to choose pharmacoepidemiology as their area of research. Major lacunae pointed out by referees include lack of calculation of sample size, improper or non-existent sampling techniques, absence of statistical analysis, and a very superficial treatment of the subject matter. Pharmacoepidemiology, by its very definition, lends itself to large variety of study designs, but for reasons unknown, researchers seem to be interested in conducting only quantitative drug utilization studies. While these studies are necessary for hypothesis generation, why is no one interested in testing a hypothesis or conducting interventional studies? Almost all papers in this area consist of analyzing a specific number of prescriptions and looking at the different classes of drugs prescribed, the number of drugs per prescription, the number of fixed dose drug formulations, injectibles and so on [5]. Most of the studies do not take it even one step further to assess whether each prescription was rational or not; probably out of fear of rubbing the clinicians on the wrong side and also out of the lack of standard treatment guidelines in many facilities. Even quantifying the drug use by using internationally accepted measures such as 'Defined Daily Dose' is not done. Two decades ago, studies which compared the drug utilization patterns of various departments in health care facilities by looking at "N" prescriptions were "publishable" material. It is no longer so $[6,7]$. The rapid strides in both quantitative and qualitative research methodology as well as sophisticated statistical analytical methods make it imperative that the "proper tools of epidemiological research" are used. Pharmacologists seeking to does research in pharmacoepidemiology should take the time and make the effort to learn the basic concepts of epidemiological research and ensure that the basic principles are satisfactorily addressed during planning [8]. Any study describing factors which affect drug use in the community-be it compliance to therapy or drug metabolizing enzymes, must use the appropriate sampling techniques and methods to draw valid conclusions. Citing the example of earlier studies which lacked these requisites is not justified, since as in any field, research should be conducted using methods appropriate and commensurate with the developments in the field $[9,10]$. "Pharmacoepidemiology is a powerful tool that can benefit patients and public health, but only if used appropriately.

\section{References}

1. Wahbi AA, Hassan E, Hamdy D, Khamis E, Barary M (2005) Spectrophotometric methods for the determination of Ibuprofen in tablets. Pak J Pharm Sci 18: 1-6

2. Hughes L, Whittlesea C, Luscombe D (2002) Patient's knowledge and perception of side-effects of OTC medication. J Clin Pharm Ther 27: 243-248.

3. Bardel A, Wallander MA, Svardsudd K (2000) Reported current use of perscription drugs and some of its determinants among 35 to 65 year-old women in mid-Sweden. J Clin Epidemiol 53: 637-643.

4. Antal EJ, Wright CE 3rd, Brown BL, Albert KS, Aman LC, et al. (1986) The influence of hemodialysis on the pharmacokinetic of ibuprofen and its major metabolites. J Clin Pharmacol 26: 184-190.

5. Adams SS, McCullough KF, Nicholson JS (1969) The pharmacological properties of ibuprofen, an anti inflammatory, analgesic and anti pyretic agent. Arch Int Pharmacodyn Ther 178: 115-129.

6. Rifai N, Sakamoto M, Law T, Galpchian V, Harris N, et al. (1996) Use of a rapid HPLC assay for determination of pharmacokinetic parameters of ibuprofen in paients with cystic fibrosis. Clin Chem 42: 1812-1816.

7. Karttunen P, Saano V, Paronen P, Peura P, Vidgren M (1990) Pharmacokinetics of ibuprofen in man: a single-dose comparison of two over the counter, $200 \mathrm{mg}$ preparations. Int J Clin Pharmacol Ther Toxicol 28: 251-255.

8. Pepper GA (2000) Non steroidal anti inflammatory drugs; New perspectives on a familiar drug class. Nurs Clin North Am 35: 223-244.

9. Ton TG, Heckbert SR, Longstreth WT Jr, Rossing MA, Kukull WA, et al. (2006) Non steroidal anti inflammatory drugs and risks of Parkinson's disease. Mov Disord 21: 964-969.

10. Bell EC, Ravis WR, Lloyd KB, Stokes TJ (2007) Effects of St. John's wort supplementation on ibuprofen pharmacokinetics. Ann Pharmacother 41: 229234

*Corresponding author: Suman Garlapati, Drug Safety \& Pharmacovigilance Officer InvaGen Pharmaceuticals, Inc. Hauppauge, New York 11788, USA, Tel: (631) 2313233 Fax: (631) 231 4288; E-mail: suman@invagen.com

Received April 26, 2012; Accepted April 26, 2012; Published April 28, 2012

Citation: Garlapati S (2012) Pharmacoepidemiology - A Lot beyond Pencil and Paper Research. Adv Pharmacoepidem Drug Safety 1:e103. doi:10.4172/ 2167-1052.1000e103

Copyright: (c) 2012 Garlapati S. This is an open-access article distributed under the terms of the Creative Commons Attribution License, which permits unrestricted use, distribution, and reproduction in any medium, provided the original author and source are credited. 